This item was submitted to Loughborough's Research Repository by the author.

Items in Figshare are protected by copyright, with all rights reserved, unless otherwise indicated.

\title{
The aquatic macroinvertebrate biodiversity of urban ponds in a medium- sized European town (Loughborough, UK)
}

PLEASE CITE THE PUBLISHED VERSION

http://dx.doi.org/10.1007/s10750-015-2328-8

\section{PUBLISHER}

(c) Springer International Publishing

\section{VERSION}

AM (Accepted Manuscript)

\section{PUBLISHER STATEMENT}

This work is made available according to the conditions of the Creative Commons Attribution-NonCommercialNoDerivatives 4.0 International (CC BY-NC-ND 4.0) licence. Full details of this licence are available at: https://creativecommons.org/licenses/by-nc-nd/4.0/

\section{LICENCE}

CC BY-NC-ND 4.0

\section{REPOSITORY RECORD}

Hill, Matthew J., Paul J. Wood, and Kate L. Mathers. 2019. "The Aquatic Macroinvertebrate Biodiversity of Urban Ponds in a Medium-sized European Town (loughborough, UK)". figshare. https://hdl.handle.net/2134/18381. 
1 The aquatic macroinvertebrate biodiversity of urban ponds in an European town (Loughborough, UK)

2 M. J. Hill, K. L. Mathers and P. J. Wood ${ }^{1}$

3

$4 \quad{ }^{1}$ Centre for Hydrological and Ecosystem Science, Department of Geography, Loughborough

5 University, Loughborough, Leicestershire, LE11 3TU, UK

6

$7 \quad$ Author for correspondence

8 Matthew J. Hill

9 Department of Geography

10 Loughborough University

11 Loughborough

12 Leicestershire

13 LE11 3TU

14 UK.

15

16 Tel: $0044(0) 1509222751$

17 Email: m.j.hill@lboro.ac.uk

19 Abstract 
1 Urbanization is one of the greatest threats to freshwater biodiversity, with the area of land covered by

2 towns and cities predicted to increase significantly in the future. Ponds are common features in the

3 urban landscape and have been created for a variety of reasons ranging from ornamental/amenity

4 purposes through to the detention of urban runoff and pollution. This paper aims to quantify the

5 aquatic macroinvertebrate biodiversity associated with garden, ornamental and other urban ponds in

6 Leicestershire, UK. We examined the macroinvertebrate biodiversity of 41 urban ponds (13 garden,

712 park and 16 other urban ponds) within the town of Loughborough, UK. Park ponds supported

8 greater macroinvertebrate richness than garden or other urban ponds. Garden ponds were the most

9 taxon poor. Pond size was strongly correlated with macroinvertebrate diversity. Collectively, urban

10 ponds were found to be physically and biologically heterogeneous and were characterised by high

11 community dissimilarity. Urban ponds provide a diverse range of habitats for a mixture of common

12 and rare aquatic macroinvertebrate taxa and represent a valuable biodiversity resource within

13 anthropogenically dominated landscapes. Recognition of the significant contribution of ponds to

14 urban freshwater biodiversity is important for future aquatic conservation within anthropogenically

15 dominated landscapes.

16 Key Words: urbanization, small lentic waterbodies, artificial habitat, anthropogenic ecosystems,

17 macroinvertebrate, pond management 
2 The proportion of landscape covered by urban development has significantly increased globally in the

3 last century and human populations are becoming more concentrated within cities (United Nations, 4 2014). Urbanized land is projected to increase up to $185 \%$ from current levels by 2030 (Seto et al., 5 2012) and $66 \%$ of global population is predicted to live in urban areas by 2050 (United Nations, 6 2014). The threat of urbanization to biodiversity has been well documented (McKinney, 2002; 7 Shochat et al., 2010) and the widespread increase in urban land-cover has resulted in the 8 fragmentation of wildlife habitats in the wider landscape (Goddard et al., 2010), and a reduction in 9 species richness (McKinney, 2002; McKinney, 2008). Urbanization has been widely reported to result 10 in habitat and biotic homogenization, increased disturbance frequency and implicated in the 11 successful introduction and proliferation of non-native taxa (Grimm et al., 2008; Niinemets \& 12 Penuelas, 2008). However, floral richness has been identified to peak at moderate levels of urbanization (McKinney, 2008).

14 Urban spaces can be largely characterized into two groups; 1) highly developed landscapes such as 15 residential, commercial and industrial spaces and; 2) open areas including parks, wasteland and 16 domestic gardens (Goertzen \& Suhling, 2013). As the population within urban areas increases, 17 compact developments with high density commercial and residential areas (buildings and urban 18 infrastructure) will expand at the expense of open 'green' spaces (Dallimer et al., 2011). This is likely 19 to put further pressure on urban biodiversity, potentially leading to increased local extinction rates 20 (Sushinsky et al., 2013).

21 The growing need for the protection and conservation of freshwater biodiversity has been raised on 22 the international political agenda in recent years. The United Nations launched and supported an 23 international decade (2005-2015) for action on 'water for life' with a special emphasis on highly 24 modified and fragmented landscapes (Dudgeon et al., 2006). Many freshwater waterbodies located 25 within urban landscapes are under significant pressure from anthropogenic disturbances (Urban et al., 26 2006) including pollution (Paul \& Mayer, 2001; Dudgeon et al., 2006) and habitat modification / loss 
1 (Gopal, 2013). Conservation and management of biodiversity within urban areas currently relies

2 heavily on the designation of areas protected by planning or regulatory outcomes (Mcdonald et al.,

3 2008; Chester \& Robson, 2013). However, the sustainable management of biodiversity should not be

4 expected to depend exclusively on protected sites as growing urban populations and land-cover

5 change are projected to threaten many existing designated areas (Chester \& Robson, 2013; Guneralp

$6 \&$ Seto, 2013). Research addressing the biodiversity of urban regions has historically focused on

7 terrestrial and lotic habitats (e.g., Paul \& Mayer, 2001; Fontana et al., 2011), with research

8 specifically quantifying aquatic macroinvertebrate biodiversity within urban ponds being limited (e.g.,

9 Gledhill et al., 2008; Goertzen \& Suhling, 2013; Briers, 2014; Noble \& Hassall, 2014; Hassall \&

10 Anderson, 2015). The increase in urban land-cover highlights the pressing need to examine urban

11 biodiversity of small lentic waterbodies (ponds) in an increasingly challenging environment. Ponds

12 within urban landscapes have been created for a variety of reasons including: i) ornamental and

13 amenity purposes (e.g., garden, urban park and school ponds); ii) to reduce urban runoff and / or

14 improve urban water quality (e.g., sustainable urban drainage ponds and detention ponds) (Heal et al.,

15 2006; Williams et al., 2013; Hassall, 2014) and; iii) industrial ponds (remnant and current e.g., mill

16 ponds) that were created historically and persist, although their original function may be redundant

17 (Wood et al., 2001). It is widely recognised that ponds are abundant in urban landscapes (Goertzen \&

18 Suhling, 2013) and many persist due to their amenity value (Wood et al., 2003). As urban landscape

19 features, ponds are typically aesthetically pleasing to the general public, small in size and as a result

20 perceived to be relatively easy to manage (Biggs et al., 1994), and thus may provide a relatively easy

21 but effective means to conserve aquatic biodiversity.

22 Ponds are acknowledged to support high aquatic faunal and floral diversity at a regional scale and 23 provide important habitats for a number of rare and endemic species in the urban and wider 24 environment (Williams et al., 2003; Biggs et al., 2005; Colding et al., 2009; Goertzen and Suhling, 25 2013). Their physicochemical heterogeneity affords a wide range of niches for aquatic 26 macroinvertebrate taxa (Williams et al., 2003), making them suitable habitats for a wide range of taxa.

27 Many macroinvertebrate species are active colonisers and can migrate between ponds, with well- 
1 connected pond networks typically supporting very high macroinvertebrate biodiversity (Gledhill et

2 al., 2008; Williams et al., 2008).

3 This paper specifically aims to quantify the aquatic macroinvertebrate biodiversity associated with

4 different types of urban pond. A wide variety of pond types are present in town and city regions

5 ranging from those located in urban parks, urban drainage detention ponds and garden ponds (Hassall,

6 2014). We sought to test the following research questions: i) Is aquatic macroinvertebrate biodiversity

7 related to pond size and location in the urban landscape (garden, parkland and other urban settings)?

8 ii) Does macroinvertebrate community heterogeneity ( $\beta$ diversity) vary among urban pond types as a

9 result of microhabitat availability and physicochemical variability?

\section{Materials and methods}

\section{Study sites}

13 The town of Loughborough (Leicestershire, UK) covers an area of approximately $35 \mathrm{~km}^{2}$ and has a 14 total population of approximately 60,000 . A total of 41 ponds were sampled in the town of 15 Loughborough and the surrounding urban environment. Three types of urban ponds were examined in detail: i) 13 garden ponds - typically small water bodies located within the boundary of an urban

17 domestic residential building; ii) 12 park ponds - waterbodies of varying size located within public spaces (e.g., parks), serving as amenity features and typically with easy access to some or all of the pond perimeter (Hassall, 2014) and; iii) 16 other urban ponds - those that did not fit into a category but varied in size and were located in high density, compact developments often on private land with controlled access (these comprised 9 urban drainage ponds - 5 of which were ephemeral in nature and dried at least once during the survey period, 4 located within school grounds and used as wildlife / education tools and 3 ponds surrounded by high density commercial developments). Urban ponds of all types frequently have a concrete / synthetic substrate / base, steep bank sides and may hold water on a permanent or temporary basis. 


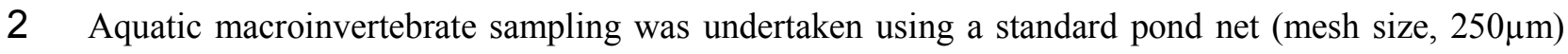
3 with the total time (maximum 3 minutes; Biggs et al., 1998) used to sample each pond being 4 proportional to its surface area (Hinden et al., 2005). Ponds with a surface area greater than $50 \mathrm{~m}^{2}$ were 5 sampled for a total of three minutes; for smaller ponds 30 seconds of sampling for every $10 \mathrm{~m}^{2}$ surface area was employed. In addition, a manual inspection of any hard surfaces or larger substrates (e.g., rocks) was undertaken for up to 60 seconds to ensure that all available microhabitats and surfaces were examined. This method recognises both the size of the waterbody and the habitat diversity contained within it. However, other sampling methods could yields greater diversity of particular macroinvertebrate taxa (e.g., Odonata) such as sampling for 15 to 20 minutes (Ruggiero et al., 2008).

11 Macroinvertebrate samples were taken on three occasions coinciding with the spring, summer and autumn seasons (high, intermediate and low water levels respectively) in each pond. For each pond the presence and proportion ( $\%$ of surface area) of aquatic microhabitats were recorded within the following categories; i) open water, ii) submerged vegetation, iii) emergent vegetation and; iv) floating vegetation. The total sampling time at each pond was divided equally between the microhabitats present. However, if an individual pond was dominated by a single microhabitat, sample time was divided further to reflect this (Biggs et al., 1998). In the laboratory, invertebrate samples from each habitat were processed separately and preserved in $70 \%$ industrial methylated spirits prior to identification. The majority of invertebrate fauna was identified to species level, although Diptera larvae, Planariidae, Collembola and Hydrachnidiae were identified to the lowest possible taxonomic level.

\section{Environmental data collection}

23 At each pond site, surface area $\left(\mathrm{m}^{2}\right)$, mean water depth $(\mathrm{cm})$, hydroperiod (duration during the 1224 month study period that the pond contained water or was dry), the percentage of the pond margin and 25 pond surface shaded by overhanging vegetation, substratum composition (percentage gravel, sand and silt), bank structure (percentage natural earth, wood, synthetic concrete and stone), the presence of 
1 fish and evidence of pollution were recorded. Conductivity $\left(\mu \mathrm{S} \mathrm{cm}^{-1}\right), \mathrm{pH}$ and water temperature, were

2 recorded in the field using a Hanna conductivity meter (HI198311) and a Hanna pH meter (HI98127).

3 Dissolved oxygen (DO $\mathrm{mg}^{-1}$ ) was recorded at each pond site using a Mettler Toledo Dissolved

4 Oxygen Meter (SG6). Pond connectivity, the number of hydrological connections to other

5 waterbodies, and pond isolation, the number of other waterbodies within 500m (Waterkeyn et al.,

6 2008), were recorded using GIS software (ArcMap 10.1). Every attempt was made to record all

7 waterbodies within $500 \mathrm{~m}$ of each pond site, however garden ponds associated with small domestic

8 dwellings were particularly difficult to identify as they were not recorded on national maps (OS

9 MasterMap) and difficult to observe using aerial images provided by Google Earth software (Google

10 Earth, 2015). As a result it is acknowledged that a small number of garden ponds may have been

11 missed.

\section{Statistical analyses}

13 Community abundance (total number of individuals per site), taxon richness and alpha diversity 14 indices (Shannon Wiener Diversity index and the Berger Parker Dominance index) were calculated 15 for each pond site and microhabitat using the Species Diversity and Richness IV software (Pisces 16 Conservation, 2008). To achieve this all species abundance data for individual ponds - for each season 17 (total diversity), and for the individual microhabitats within them (e.g., diversity within the submerged 18 macrophyte habitat during spring, summer and autumn), were combined in the final analysis to 19 provide a measure of diversity within each pond and microhabitat respectively. Prior to statistical analysis the data were examined to ensure that they complied with the underlying assumptions of parametric statistical tests (e.g., normal distribution). Where these assumptions were violated (e.g., for community abundance data) they were $\log _{10}$ transformed. Differences in faunal biodiversity among

23 the pond types and microhabitats (open water, emergent macrophytes, submerged macrophytes and

24 floating macrophytes) were examined using a nested analysis of variance (nested ANOVA) with 25 subsequent use of Tukey post hoc tests to determine where significant differences between groups 26 occurred (Van de Meutter et al., 2005). Pond type and microhabitat were included as fixed effects and 
1 site was nested within pond type as a random effect. One-way analysis of variance was used to

2 examine differences in physicochemical parameters among the ponds. Pearson correlation coefficients

3 between environmental parameters and invertebrate community metrics were calculated and scatter

4 plots inspected. Analyses were undertaken in IBM SPSS Statistics (version 21, IBM Corporation,

5 New York). Beta ( $\beta$ ) diversity was measured using Jaccard's Coefficient of Similarity (Cj: using total

6 pond macroinvertebrate data) in the Community Analysis Package 3.0 program (Pisces Conservation,

7 2004). Differences in Jaccard's Coefficient of Similarity among the ponds were assessed using one-

8 way analysis of variance (ANOVA). Heterogeneity of macroinvertebrate communities between urban

9 pond sites were assessed using Analysis of Similarity (ANOSIM) in PRIMER v6 (Clarke \& Gorley,

10 2006). Faunal abundance data was $\log (\mathrm{X}+1)$ transformed prior to ANOSIM.

11 The relationship between macroinvertebrate assemblages and physicochemical gradients was 12 examined using Redundancy Analysis (RDA) in CANOCO 4.5 (Leps \& Smilauer, 2003). Due to 13 natural seasonal variability in community composition, seasonal data from individual pond sites were 14 combined and mean values of environmental parameters derived. Environmental parameters were $15 \log _{10}$ transformed prior to analysis to reduce the influence of skew and eliminate their physical units 16 (Legendre \& Birks, 2012). Faunal abundance data was Hellinger transformed following the approach 17 of Legendre \& Gallagher (2001). The statistical significance of associations between each of the 18 environmental variables and the RDA axes were determined using a forward selection procedure, 19 employing a random Monte-Carlo permutations test (999 random permutations) with Bonferroni 20 correction. Only the physical, chemical and spatial parameters significantly influencing the faunal 21 distribution $(\mathrm{p}<0.05)$ were included in the final model.

\section{Results}

\section{Physicochemistry}


1 Physicochemical conditions varied widely among all urban ponds. Dissolved oxygen, pH,

2 conductivity, percentage of pond margin / water surface area shaded, submerged macrophytes and

3 emergent macrophytes were not significantly different between urban pond types (all ANOVA

$4 \mathrm{p}>0.05$ ). Where submerged macrophytes were present there was often a diverse range of taxa

5 including Characeae, Elodea spp. and Haloragaceae. Emergent macrophyte microhabitats were

6 dominated by sedges and reeds, whilst floating macrophyte microhabitats were dominated by Lemna

7 spp. Post hoc analysis indicated that park ponds had a significantly greater mean surface area

8 (ANOVA $\left.F_{2,40}=43.282 ; p<0.001\right)$ and depth (ANOVA $\left.F_{2,40}=15.963 ; p<0.001\right)$ than other urban and

9 garden ponds when all sampling dates were considered. Other urban ponds were significantly larger

10 than garden ponds. The proportion of the surface area covered by floating macrophytes was

11 significantly higher in garden ponds than the other pond types (ANOVA $\mathrm{F}_{2,40}=9.960 ; \mathrm{p}<0.001$ ).

Macroinvertebrate biodiversity

13 The mean abundance of aquatic invertebrates recorded from all urban ponds was 1880 , with the 14 lowest recorded within garden ponds (mean: 863, range: 45-2379), followed by other urban (mean: 15 2013, range: 39-6766) and park ponds (mean: 2804, range: 303-6628). A total of 170 taxa were 16 recorded from 18 orders and 60 families from the garden (total: 44 taxa, range: 2-24), other urban 17 (total: 91 taxa, range: 3-42) and park ponds (total: 149 taxa, range: 4-61). The invertebrate taxa most 18 widely distributed across the urban pond sites were: Chironomidae (40 ponds), Oligochaeta (40 19 ponds), Asellus aquaticus (Isopoda: Asellidae) (27 ponds) and Crangonyx pseudogracilis 20 (Amphipoda: Gammaridae) (25 ponds). Four nationally scarce or nationally notable Coleoptera were 21 recorded within the urban ponds; Helochares punctatus (Hydrophilidae), Agabus uliginosus 22 (Dytiscidae) and Gyrinus distinctus (Gyrinidae) were all recorded once within 3 separate park ponds 23 and Helophorus strigifrons (Hydrophilidae) was recorded from 1 other urban pond and 1 park pond.

24 Two non-native taxa were recorded from the urban ponds examined. The most widespread non-native 25 taxon was the amphipod Crangonyx pseudogracilis recorded from 61\% (25) of the ponds (5 garden ponds, 9 other urban ponds and 11 park ponds) and was abundant (accounting for up to 68\% of 
1 community abundance) in many of the sites where it occurred. The non-native Gastropoda,

2 Potamopyrgus antipodarum (Gastropoda: Hydrobiidae) was recorded from $22 \%$ of the ponds (4 other

3 urban ponds and 5 park ponds). Examination of community indices in association with

4 physicochemical and spatial characteristics indicated that the most significant correlations were

5 recorded between water surface area $\left(\log _{10}\right)$ and community abundance $\left(\log _{10}\right)$, taxon richness,

6 Shannon Wiener diversity, and the Berger Parker Dominance index (Fig. 1). The area of the pond

7 margin shaded and pond connectivity to other waterbodies also displayed a number of significant

8 correlations with community parameters (Table 1).

9 A significant difference in community abundance among the three urban pond types was recorded 10 (ANOVA $\mathrm{F}_{38,143}=3.627 ; \mathrm{p}<0.001$ ) (Fig. 2). Post hoc analysis indicated that community abundance 11 was significantly greater in park and other urban ponds than garden ponds $(p<0.05)$. The greatest 12 number of taxa recorded was from a park pond (61 taxa) located within an urban green space. Park 13 ponds supported significantly higher taxon richness (ANOVA $F_{38,143}=2.917 ; p<0.001$ ) than the other 14 two pond types (Fig. 2b). The Shannon Wiener Diversity index was significantly higher within park 15 than 'other' urban ponds and garden ponds (ANOVA $\left.F_{38,143}=3.945 ; p<0.001\right)$ (Fig. $2 \mathrm{c}$ ), and was also 16 recorded to be significantly higher in other urban ponds compared to garden ponds. The Berger Parker 17 Dominance index indicated that garden ponds were dominated by a small number of 18 macroinvertebrates compared to other urban or park ponds $\left(\right.$ ANOVA $\left.\mathrm{F}_{38,143}=2.551 ; \mathrm{p}<0.001\right)$ 19 (Fig.2d).

20 When individual microhabitats (open water, emergent, submerged and floating leaved macrophytes) 21 were examined, a significant difference in the number of taxa (ANOVA $\left.F_{3,143}=9.988 ; p<0.001\right)$ and 22 community abundance (ANOVA $\left.\mathrm{F}_{3,143}=6.621 ; \mathrm{p}<0.001\right)$ was observed among urban ponds. Faunal 23 abundance was typically greater in submerged and floating leaved macrophytes, with the exception of 24 garden ponds where floating leaved macrophytes contained fewer individuals (Fig. 2a). Taxon 25 richness was higher within submerged macrophytes and emergent macrophytes than open water and 
1 floating macrophytes across all pond types (Fig. 2b). The Berger Parker Dominance index and

2 Shannon Wiener Diversity Index did not differ among microhabitats ( $p>0.05)$ (Fig. 2c and Fig. 2d).

\section{Community heterogeneity}

4 A significant difference in community composition was recorded between garden and park ponds 5 (ANOSIM $\mathrm{p}<0.001)$. Discrete groups of park and garden ponds were observed within the RDA 6 ordination plot (Fig. 3) suggesting that garden and park ponds supported distinct invertebrate 7 communities. Other urban ponds were widely dispersed and overlapped all other pond types in the 8 RDA biplot. Other urban ponds had significantly lower Jaccard's Coefficient of Similarity value $\left(\mathrm{C}_{\mathrm{j}}=\right.$ $90.19)$ than garden pond sites $\left(C_{j}=0.27\right)$ and park pond sites $\left(C_{j}=0.24\right)\left(\right.$ ANOVA $F_{2,263}=10.897$ $10 \mathrm{p}<0.001)$. When all urban ponds were considered urban pond macroinvertebrate community 11 composition was highly heterogeneous $\left(C_{j}=0.18\right)$ indicating that there was marked heterogeneity $(\beta$ 12 diversity) in the macroinvertebrate communities recorded within individual urban ponds.

Macroinvertebrate community - environmental parameters relationships

14 Redundancy Analysis (RDA) of the pond macroinvertebrate community data and environmental parameters highlighted clear differences between the three urban pond types. The RDA axes were highly significant (Monte Carlo significance test: $F=2.038 \mathrm{p}<0.002$ ) with the first four axes explaining

$1726.1 \%$ of the variation in species data (axis $1: 11.4 \%$, axis $2: 6.8 \%$, axis $3: 5.7 \%$ and axis $4: 2.2 \%$ ) and $1896 \%$ of the taxa-environment relationship (axis $1: 42.1 \%$, axis $2: 24.7$, axis $3: 21.1 \%$ and axis $4: 8.1$ ). 19 Forward selection identified five significant physicochemical variables correlated with the first two RDA axes: water surface area, $\mathrm{pH}$, emergent macrophytes (all $\mathrm{p}<0.005)$, submerged macrophytes and the dry phase $(\mathrm{p}<0.05)$ (Fig. 3a). Pond connectivity and pond isolation did not significantly influence urban pond macroinvertebrate community composition in the analysis.

23 When the invertebrate assemblages of the three pond types were examined in relation to 24 environmental variables, park and garden pond invertebrate communities were separated on the first 25 and second axes along gradients associated with pond surface area and emergent and submerged 
1 macrophyte cover (Fig. 3a). Park ponds were characterised by a greater water surface area, and 2 emergent and submerged macrophyte cover, whilst garden ponds were characterised by smaller 3 surface areas and less emergent and submerged macrophytes (Fig. 3a). Other urban ponds had highly

4 variable environmental characteristics but were associated with greater proportions of emergent 5 macrophyte cover, a small surface area and a dry phase; a small number were ephemeral (5 ponds) 6 and dried during one survey, and plotted at the positive end of axis 2 (Fig. 3a). Urban ponds with the 7 greatest taxon richness and Shannon Wiener diversity were typically associated with greater water 8 surface area, greater submerged macrophytes and emergent macrophytes (Fig. 3b and Fig. 3c).

9 The RDA faunal plot indicated several species of Odonata (e.g., Aeshna mixta and Erythromma 10 najas), Hemiptera (e.g., Sigara dorsalis, Notonecta glauca and Corixa punctata), Coleoptera (e.g., 11 Haliplus confinis and Noterus clavicornis) and Gastropoda (Lymnaea stagnalis and Segmentina complanata) were associated with ponds with larger surface areas (Fig. 4). In addition, a number of 13 Coleoptera (Hydrobius fuscipes, Agabus sturmii, Dytiscidae larvae and Hydroporus pubescens), and 14 Gastropoda (e.g., Lymnaea peregra and Potamopygrus antipodarum) were associated with ponds that 15 had high emergent macrophyte cover (Fig. 4). Taxa associated with submerged macrophytes included several species of Hemiptera (e.g., Sigara falleni, Sigara distincta and Callicorixa praeusta) and

17 Trichoptera (e.g., Limnephilus marmoratus and Phryganea bipunctata). Relatively high abundances of Diptera larvae (Chironomidae, Simuliidae and Culicidae) were typically recorded within garden ponds (Fig. 4). Psychodidae, Scirtidae larvae, Collembola and Stratiomyidae were associated with ephemeral ponds and plotted at the positive end of RDA-axis 1 (Fig. 4).

\section{Discussion}

Macroinvertebrate diversity

24 Park ponds in this study were recorded to support the greatest invertebrate richness whilst garden 25 ponds were found to support the lowest diversity among the three urban pond types and were 
1 frequently dominated by dipteran larvae. However, it is important to acknowledge that Diptera were

2 only identified to family level in this study and it is likely that garden ponds may support high 3 dipteran species diversity that has not been quantified in this study. Garden ponds in Sheffield, UK, 4 were also dominated by Diptera larvae and supported a limited number of invertebrate taxa (Gaston et 5 al., 2005a). The high macroinvertebrate diversity recorded from park ponds in this study was greater 6 than that recorded from urban ponds in Halton (Lancashire, UK): total $=119$ taxa, and urban drainage 7 ponds in Dunfermline (Fife, UK): total $=66$ taxa (Gledhill et al., 2008; Briers, 2014). A significant 8 proportion of the regional macroinvertebrate species pool (228 taxa, Hill, 2015) was represented 9 within the urban ponds (170 taxa). High regional invertebrate diversity has also been recorded within aquatic urban systems in the Netherlands (Vermonden et al., 2009) and for other organisms such as waterbirds (Santoul et al., 2009) and amphibians (Brand \& Snodgrass, 2009).

12 However, at the scale of the individual pond, macroinvertebrate diversity within ponds was variable, ranging from 2 to 61 taxa. This almost certainly reflects both the physical and chemical heterogeneity 14 of the ponds, but also their location within structurally complex and highly fragmented anthropogenic settings. Many of the most taxon rich park ponds were located in 'green spaces' which may have acted as a buffer zone protecting aquatic taxa from runoff from anthropogenic surfaces and

17 disturbances. The importance of buffer zones in the conservation of amphibian populations has been highlighted (Semlitsch \& Bodie, 2003), although there has been limited research assessing their effectiveness in relation to macroinvertebrate biodiversity within ponds (Langley et al., 1995).

A positive association was observed between macroinvertebrate diversity and pond surface area in this study and is a pattern that has been documented in some (e.g., Biggs et al., 2005; Nilsson \& Svensson, 1995; Ruggiero et al., 2008) but not all pond biodiversity studies (Scheffer et al., 2006; Nakanishi et al., 2014). The significant relationship between diversity and urban pond size in this study may be the result of a reduction in predator density and greater habitat diversity in larger ponds, and greater disturbance and stochastic events in smaller ponds (Whittaker \& Fernandez-Palacios, 2007). However, Oertli et al. (2002) demonstrated that the influence of pond size can vary depending 
1 on the macroinvertebrate group; Odonata had a relatively strong correlation with pond size, whilst

2 Coleoptera, Sphaeriidae and overall faunal richness displayed a weak association with pond size. In

3 addition, research has identified that a series of smaller ponds can support a greater diversity than a

4 single larger pond (Oertli et al., 2002). The small catchment area of ponds can enable quite different

5 environmental conditions to develop (reflecting local microsite conditions and stochastic effects

6 (Scheffer et al., 2006)) even in ponds that are in close geographical proximity to each other (Davies et

7 al., 2008). This high physicochemical heterogeneity provides a wide range of conditions/niches for

8 flora and fauna to colonize and at a regional scale ponds have been demonstrated to support greater

9 aquatic macrophyte and macroinvertebrate diversity than larger ponds and other waterbodies (Oertli et

10 al., 2002; Williams et al., 2003; Biggs et al., 2005).

11 The proximity of urban ponds to other waterbodies was not identified as a significant influence on macroinvertebrate community composition in this study. Urban ponds, especially those in domestic gardens are often surrounded by walls, fences or buildings (barriers), typical of urban landscapes.

14 These physical barriers may significantly reduce pond connectivity and the ability of invertebrate taxa to disperse or colonise new habitats, even if they are in close geographical proximity. Urban ponds with greater hydrological connectivity to other waterbodies were significantly correlated with macroinvertebrate diversity and highlight the importance of even ephemeral linkages in the landscape (e.g., ditches, ephemeral channel and/or connectivity resulting from flooding) for the dispersal and colonisation of taxa between urban ponds. The small size of garden ponds (typically around $10 \mathrm{~m}^{2}$ ), their management practices (e.g., maintenance of open water, reduced macrophyte cover and/or actively managed to prevent succession) and their high turn-over, due to changes in house ownership and garden management fashions, may significantly limit the ability of garden ponds to replicate the habitat diversity of ponds within the wider urban and rural landscape (Gaston et al., 2005b). However, despite these limitations and low alpha diversity, garden ponds make an important contribution to the regional urban species pool (Gaston et al., 2005a; Gledhill et al., 2008). Given the high abundances of garden ponds, estimated to be between 2.5 - 3.5 million in the UK (Davies et al., 2009), future research is required to examine their potential to serve as refugia for macroinvertebrate communities. 
1 Greater public awareness and guidance regarding the best management practices may also enhance

2 the biodiversity value of garden ponds in the future.

3

4 Substantial macroinvertebrate community heterogeneity was observed within and between urban pond

5 types. The high community dissimilarity recorded demonstrates that urban ponds provide a range of

6 habitats / niches for invertebrate taxa to utilise. Other urban ponds in this study were shown to have a

7 high dissimilarity in community composition. This reflects the varying pond successional stages, the

8 diverse physicochemical characteristics and management practices (there were a wide range of pond

9 types in the other urban pond group, e.g., stormwater retention ponds, golf course ponds and school

10 ponds) observed among the other urban ponds (Biggs et al., 1994; Williams et al., 2003; Nicolet et al.,

11 2004; Biggs et al., 2005). This inter-pond, spatial dissimilarity also reflects the different levels of

12 management that urban ponds are subject to; ranging from regular active management through to an

13 absence of intervention. Macroinvertebrate communities from ponds in the wider landscape have also

14 been shown to display significant temporal heterogeneity and turnover of species, which can cause

15 temporal variation in the conservation value of pond habitats (Jeffries, 2011; Hassall et al., 2012).

16 Future research is required to examine the nature of temporal heterogeneity of urban pond

17 communities and the implications for the conservation of urban biodiversity.

Urban pond conservation and management

19 Despite their largely anthropogenic origin and the presence of several non-native taxa $(C$. 20 pseudogracilis and $P$. antipodarum) the results clearly demonstrate that many urban ponds can support species rich invertebrate communities including taxa of conservation interest (Hassall \&

22 Anderson, 2015). Urban ponds potentially have a vital role to play in reducing aquatic habitat

23 fragmentation and serving as stepping stones in anthropogenic / disturbed landscapes (Chester \&

24 Robson, 2013). Ponds not only contribute to ongoing conservation efforts but may actively enhance

25 freshwater biodiversity in the urban region (Le Viol et al., 2009; Vermonden et al., 2009; Briers, 
1 2014). In common with other studies of urban ponds this research indicated that the majority

2 supported generalist taxa (Gledhill et al., 2008; Goertzen \& Suhling, 2013; Briers, 2014). However,

3 urban ponds may be particularly important habitat for motile taxa such as Coleoptera and Odonata

4 which can opportunistically colonise available habitat aerially (Scher \& Thiery, 2005; Goertzen \&

5 Suhling, 2013). A number of these active colonisers with an aerial adult life-stage were well

6 represented and among the most species rich groups recorded (Coleoptera, Trichoptera and

$7 \quad$ Hemiptera) in the urban ponds studied.

8 However, this study, and others (Noble \& Hassall, 2014) have also demonstrated that a large number

9 of urban ponds are species poor and of a low conservation value. Poor quality urban ponds are often

10 not reported as they are considered uninteresting (Hassall, 2014). It has been identified that

11 approximately $80 \%$ of ponds in England and Wales are of a poor or very poor quality (Williams et al.,

12 2010). Lower quality, degraded urban ponds may act as ecological traps for macroinvertebrate taxa

13 unable to detect anthropogenic disturbance prior to colonising. Participation of the general public in

14 urban pond conservation / management, such as pond warden schemes, may help ensure ponds are

15 preserved in the urban environment and could augment urban aquatic biodiversity (Boothby, 1995;

16 DCPWA, 2014). Pond warden schemes, currently in operation in a small number of UK cities, allow a

17 larger number of urban ponds to be monitored and managed in a more strategic manner and could

18 greatly improve the ecological quality of degraded urban ponds at a national scale. It is also important

19 to recognise that ponds located in urban spaces (e.g., school, or public park) provide an opportunity

20 for the general public to interact with freshwater ecosystems and may help to engage the non-

21 scientific community in biological conservation and raise awareness of the importance and

22 management needs of small freshwater habitats (Hassall, 2014).

23 A number of observations and considerations regarding urban pond management can be made from

24 this study. First, the creation of new urban ponds should be encouraged wherever it is practical and

25 possible. The design of the pond should reflect its primary purpose; for example an ornamental plant

26 pond may have vertical sides to ensure a constant water depth while a pond to support amphibians 
1 should include shallow shelves to allow individuals to leave the pond (Smith \& Sutherland, 2014). In

2 other instances, the requirements of the target floral and faunal group may need to be specifically

3 considered (e.g., Odonata - Goertzen \& Suhling, 2013) or for biodiversity more generally (Bardsley,

4 2012). Second, the results of this research demonstrated that the greatest macroinvertebrate diversity

5 was recorded within the emergent and submerged macrophyte habitats. Management practices to

6 support macroinvertebrate biodiversity should therefore aim to maintain or enhance submerged and

7 emergent macrophyte habitats; although other habitats including areas of open water should also be

8 maintained to support open water specialist taxa. Third, the area and immediate landuse surrounding a

9 pond should be considered since the presence of a buffer-zone may enhance the aesthetic value, as

10 well as mitigating the effects of anthropogenic disturbances and large urban structures. Physical

11 barriers (e.g., high walls / fences and surrounding buildings) will influence colonisation and dispersal

12 routes for organisms. Finally, urban ponds should be considered as part of the wider landscape /

13 pondscape wherever possible. Pond warden schemes may help facilitate this and ensure that

14 appropriate and sensitive management operations are undertaken but also that a wide range of pond

15 types (including ephemeral ponds and those at both early and late successional stages) exist to ensure

16 that both urban and wider landscape biodiversity is maximised wherever possible.

\section{Conclusion}

19 Ponds are common and abundant features in the urban landscape, many of which have anthropogenic 20 origins and were built for a range of purposes including public amenity, flood reduction and water treatment. Urban ponds can support rich and diverse macroinvertebrate communities and in this study,

22 park ponds supported the highest macroinvertebrate diversity whilst domestic garden ponds were the 23 most taxa poor. Pond size was found to be strongly associated with macroinvertebrate diversity and

24 the high beta diversity recorded demonstrates that individual ponds support different communities and 25 that they potentially make an important contribution to regional biodiversity. A number of practical 26 management recommendations have been suggested to increase aquatic macroinvertebrate 
1 biodiversity in anthropogenically dominated urban areas. Irrespective of their biodiversity and 2 conservation value, it is important to recognise that urban ponds serve a number of societal functions

3 and provide an opportunity for public engagement with freshwater habitats in addition to supporting 4 biodiversity. Recognition of the significant contribution that ponds make to urban freshwater 5 biodiversity is therefore important for the future conservation and management of urban ponds and 6 other artificial waterbodies. This is vital for the ongoing protection of sites and biota from further 7 habitat fragmentation in urban landscapes.

8

\section{Acknowledgements}

10 The authors gratefully acknowledge Charnwood Borough Council, Loughborough University and the 11 home owners that granted access to ponds located in their gardens. We would like to thank the 12 anonymous reviewers for their helpful and constructive comments on a draft of this manuscript which 13 greatly improved the clarity and focus of the research. We are grateful to Stuart Ashby, Barry Kenny 14 and Danielle Ashdown for help and assistance with field and laboratory work. MJH acknowledges the 15 support of a Loughborough University Graduate School Studentship in the Department of Geography.

\section{References}

18 Bardsley, L. 2012. The Wildlife Pond Handbook: A practical guide to creating and maintaining your 19 own wetland for wildlife. New Holland Publishers: London

20 Biggs, J., Corfield, A., Walker, D., Whitfield, M., \& Williams, P. 1994. New approaches to the 21 management of ponds. British Wildlife 5: 273-287

22 Biggs, J., Fox, G., Whitfield, M. \& Williams, P. 1998. A guide to the methods of the National Pond 23 Survey, Pond Action: Oxford 
1 Biggs, J., Williams, P., Whitfield, M., Nicolet, P. \& Weatherby, A. 2005. 15 years of pond assessment

2 in Britain: results and lessons learned from the work of pond conservation. Aquatic Conservation:

3 Marine and Freshwater Ecosystems 15: 693-714

4 Boothby, J. 1995. Sustaining a threatened landscape: farmland ponds in Cheshire. Journal of

5 environmental planning and Management 38: 561-568

6 Brand, A. B. \& Snodgrass, J. W. 2009. Value of artificial habitats for amphibian reproduction in

7 altered landscapes. Conservation Biology 24: 295-301

8 Briers, R. A. 2014. Invertebrate communities and environmental conditions in a series of urban

9 drainage ponds in Eastern Scotland: implications for biodiversity and conservation value of SUDS.

10 Clean - Soil, Air, Water 42: 193-200

11 Chester, E. T. \& Robson, B. J. 2013. Anthropogenic refuges for freshwater biodiversity: Their

12 ecological characteristics and management. Biological Conservation 166: 64-75

13 Clarke, K. R. \& Gorley, R. N. 2006. PRIMER v6: User Manual/Tutorial. PRIMER E-Ltd: Plymouth, 14 UK

15 Colding, J., Lundberg, J., Lundberg, S. \& Andersson, E. 2009. Golf courses and wetland fauna.

16 Ecological Applications 19: 1481-1491

17 Dallimer, M., Tang, Z., Bibby, P. R., Brindley, P., Gaston, K. J. \& Davies, Z. G. 2011. Temporal

18 changes in green space in a highly urbanized region. Biology Letters 7: 763-766

19 Davies, B, R., Biggs, J., Williams, P., Whitfield, M., Nicolet, P., Sear, D., Bray, S. \& Maund, S. 2008.

20 Comparative biodiversity of aquatic habitats in the European agricultural landscape. Agriculture,

21 Ecosystems and Environment 125: 1-8 
1 Davies, Z. G., Fuller, R. A., Loram, A., Irvine, K. N., Sims, V. \& Gaston, K. J. 2009. A national scale

2 inventory of resource provision for biodiversity within domestic gardens. Biological Conservation

$3 \quad 142: 761-771$

4 DCPWA (2014) Derby City Pond Warden Association Website. Available at:

5 http://www.dcpwa.org.uk/ [Access Date: $30^{\text {th }}$ April 2015].

6 Dudgeon, D. et al., 2006. Freshwater biodiversity: importance, threats, status and conservation

7 challenges. Biological Reviews 81: 163-182

8 Fontana, S., Sattler, T., Bontadina, F. \& Moretti, M. 2011. How to manage the urban green to improve

9 bird diversity and community structure. Landscape and Urban Planning 101: 278-285

10 Gaston, K. J., Smith, R. M., Thompson, K. \& Warren, P. H. 2005a. Urban domestic gardens (II):

11 experimental test of methods for increasing biodiversity. Biodiversity and Conservation 14: 395-413

12 Gaston, K. J., Warren, P. H., Thompson, K. \& Smith, R. M. 2005b. Urban domestic gardens (IV): the 13 extent of the resource and its associated features. Biodiversity and Conservation 14: 3327-3349

14 Gledhill, D. G., James, P. \& Davies, D. H. 2008. Pond density as a determinant of aquatic species 15 richness in an urban landscape. Landscape Ecology 23: 1219-1230

16 Goddard, M. A., Dougill, A. J. \& Benton, T. G. 2010. Scaling up from gardens: Biodiversity

17 conservation in urban environments. Trends in Ecology and Evolution 25: 90-98

18 Goertzen, D. \& Suhling, F. 2013. Promoting dragonfly diversity in cities: major determinants and 19 implications for urban pond design. Journal of Insect Conservation 17: 399-409

20 Google Earth, 2015. https://earth.google.com [last accessed 18/03/2015]

21 Gopal, B. 2013. Future of wetlands in tropical and subtropical Asia, especially in the face of climate 22 change. Aquatic Sciences 75: 39-61 
1 Grimm, N. B., Faeth, S. H., Golubiewski, N. E., Redman, C. L., Wu, J., Bai, X. \& Briggs, J. M. 2008.

2 Global change and the ecology of cities. Science 319: 756-760

3 Guneralp, B. \& Seto, K. C. 2013. Futures of global urban expansion: uncertainties and implications of 4 biodiversity conservation. Environmental Research Letters 8: 1-10

5 Hassall, C. \& Anderson, S. 2015. Stormwater ponds can contain comparable biodiversity to 6 unmanaged wetlands in urban areas. Hydrobiologia 745: 137-149

7 Hassall, C., Hollinshead, J. \& Hull, A. 2012. Temporal dynamics of aquatic communities and

8 implications for pond conservation. Biodiversity and Conservation 21: 829-852

9 Hassall, C. 2014. The ecology and biodiversity of urban ponds. Wiley Interdisciplinary Reviews:

10 Water 1: 187-206

11 Heal, K. V., Hepburn, D. A. \& Lunn, R. J. 2006. Sediment management in sustainable urban drainage

12 system ponds. Water Science and Technology 53: 219-227

13 Hill, M. J. 2015. Aquatic macroinvertebrate biodiversity of lowland rural and urban ponds in

14 Leicestershire. Unpublished $\mathrm{PhD}$ thesis, Loughborough University

15 Hinden, H., Oertli, B., Menetrey, N., Sager, L. \& Lachavanne, J. 2005. Alpine pond biodiversity:

16 what are the related environmental variables. Aquatic Conservation: Marine and Freshwater

17 Ecosystems 15: 613-624

18 Jeffries, M. J. 2011. The temporal dynamics of temporary pond macroinvertebrate communities over a 1910 year period. Hydrobiologia 661: 391-405

20 Langley, J. M., Kett, S., Al-Khalili, R. S. \& Humphrey, C. J. 1995. The conservation value of English 21 urban ponds in terms of their rotifer fauna. Hydrobiologia 313/314: 259-266 
1 Le Viol, I., Mocq, J. Julliard, R. \& Kerbiriou, C. 2009. The contribution of motorway stormwater

2 retention ponds to the biodiversity of aquatic macroinvertebrates. Biological Conservation 142: 3163 -

$3 \quad 3171$

4 Legendre, P. \& Birks, H. J. B. 2012. From classical to canonical conservation. In: Birks, H. J. B.,

5 Lotter, A. F., Juggins, S. \& Smol, J. P. (Eds.) Tracking Environmental Change Using Lake Sediments,

6 Volume 5: Data Handling and Numerical Techniques. Springer, Dordrecht. pp. 201-248

7 Legendre, P. \& Gallagher, E. D. 2001. Ecologically meaningful transformations for ordination of

8 species data. Oecologia 129: 271-280

9 Leps, J. \& Smilauer, P. 2003. Multivariate Analysis of Ecological Data Using CANOCO. Cambridge

10 University Press: Cambridge

11 Mcdonald, R. I., Kareiva, P. \& Forman, R. T. T. 2008. The implications of current and future

12 urbanization for global protected areas and biodiversity conservation. Biological Conservation 141:

$13 \quad 1695-1703$

14 McKinney, M. L. 2002. Urbanization, biodiversity and conservation. Bioscience 52: 883-890

15 McKinney, M. L. 2008. Effects of urbanization of species richness: a review of plants and animals.

16 Urban Ecosystems 11: 161-176

17 Nakanishi, K., Nishida, T., Kon. M. \& Sawada, H. 2014. Effects of environmental factors on the

18 species composition of aquatic insects in irrigation ponds. Entomological Science 17: 251-261

19 Nicolet, P., Biggs, J., Fox, G., Hodson, M. J., Reynolds, C., Whitfield, M. \& Williams, P. 2004. The

20 wetland plant and macroinvertebrate assemblages of temporary ponds in England and Wales.

21 Biological Conservation 120: 261-278

22 Niinemets, U. \& Penuelas, J. 2008. Gardening and urban landscaping: significant player in global

23 change. Trends in Plant Science 13: 60-65 
1 Nilsson, A. N. \& Svensson, B. W. 1995. Assemblages of dytiscid predators and culicid prey in

2 relation to environmental factors in natural and clear-cut boreal swamp forest pools. Hydrobiologia

$3 \quad 308: 183-196$

4 Noble, A. \& Hassall, C. 2014. Poor ecological quality of urban ponds in northern England: causes and 5 consequences. Urban Ecosystems: 1-14

6 Oertli, B., Joye, D. A., Castella, E., Juge, R., Cambin, D. \& Lachavanne, J. B. 2002. Does pond size

7 matter? The relationship between pond area and biodiversity. Biological Conservation 104: 59-70

8 Paul, M. J. \& Mayer, J. L. 2001. Streams in the urban landscape. Annual Review of Ecology and

9 Systematics 32: 333-365

10 Pisces Conservation, 2004. Community Analysis Package Version 3.0. Pisces Conservation Ltd, 11 Lymington, UK

12 Pisces Conservation, 2008. Species Diversity and Richness IV. Pisces Conservation Ltd, Lymington, 13 UK

14 Ruggiero, A., Cereghino, R., Figuerola, J., Marty, P. \& Angelibert, S. 2008. Farm ponds make a 15 contribution to the biodiversity of aquatic insects in a French agricultural landscape. Comptes Rendus 16 Biologies 331: 298-308

17 Santoul, F., Gaujard, A., Angelibert, S., Mastrorillo. S. \& Cereghino, R. 2009. Gravel pits support 18 waterbird diversity in an urban landscape. Hydrobiologia 634: 107-114

19 Scher, O. \& Thiery, A. 2005. Odonata, amphibian and environmental characteristics in motorway 20 stormwater retention ponds (Southern France). Hydrobiologia 551: 237-251

21 Semlitsch, R. D. \& Bodie, J. R. 2003. Biological criteria for buffer zones around wetlands and 22 riparian habitats for amphibians and reptiles. Conservation Biology 17: 1219-1228 
1 Seto, K. C., Guneralp, B. \& Hutyra, L. R. 2012. Global forecasts of urban expansion to 2030 and

2 direct impacts on biodiversity and carbon pools. Proceedings of the National Academy of Sciences

3 109: 16083-16088

4 Scheffer, M., van Geest, G. J., Zimmer, K., Jeppersen, E., Sondergaard, M., Butler, M. G., Hanson,

5 M. A., Declerck, S. \& De Meester, L. 2006. Small habitat size and isolation can promote species

6 richness: second-order effects on biodiversity in shallow lakes and ponds. Oikos 112: 227-231

7 Shochat, E., Lerman, S. B., Anderies, J. M. Warren., P. S., Faeth, S. H. \& Nilon, C. H. 2010.

8 Invasion, competition, and biodiversity loss in urban ecosystems. Bioscience 60: 199-208

9 Smith, R. K. \& Sutherland, W. J. 2014. Amphibian conservation: global evidence for the effects of 10 interventions. Pelagic Publishing: Exeter

11 Sushinsky, J. R., Rhodes, J. R., Possingham, H. P., Gill, T. K. \& Fuller, R. A. 2013. How should we 12 grow cities to minimize their biodiversity impacts? Global Change Biology 19: 401-410

13 United Nations, 2014. World Urbanization Prospects: the 2014 revision. United Nations: New York

14 Urban, M. C., Skelly, D. K., Burchsted, D., Price, W. \& Lowry, S. 2006. Stream communities across a 15 rural-urban landscape gradient. Diversity and Distributions 12: 337-350

16 Van de Meutter, F., Stoks, R. \& De Meester, L. 2005. The effect of turbidity state and microhabitat on 17 macroinvertebrate assemblages: a pilot study of six shallow lakes. Hydrobiologia 542: 379-390

18 Vermonden, K., Leuven, R. S. E. W., van der Velde, G., van Katwijk, M. M., Roelofs, J. G. M. \& Jan 19 Hendriks, A. 2009. Urban drainage systems: An undervalued habitat for aquatic macroinvertebrates. 20 Biological Conservation 142: $1105-1115$

21 Waterkeyn, A., Grillas, P., Vanschoenwinkel, B. \& Brendonck, L. 2008. Invertebrate community 22 patterns in Mediterranean temporary wetlands along hydroperiod and salinity gradients. Freshwater 23 Biology 53: 1808-1822 
1 Williams, C. J., Frost, P. C. \& Xenopoulos, M. 2013. Beyond best management practices: pelagic

2 biogeochemical dynamics in urban stormwater ponds. Ecological Applications 23: 1384-1395

3 Williams, P., Biggs, J., Crowe, A., Murphy, J., Nicolet, P., Meatherby, A. \& Dunbar, M. 2010.

4 Countryside survey report from 2007, Technical report No 7/07 Pond Conservation and NERC/Centre

5 for Ecology and Hydrology, Lancaster

6 Williams, P., Whitfield, M. \& Biggs, J. 2008. How can we make new ponds biodiverse? A case study 7 monitored over seven years. Hydrobiologia 597: 137-148

8 Williams, P. Whitfield, M., Biggs, J., Bray, S., Fox, G., Nicolet, P. \& Sear, D. 2003. Comparative

9 biodiversity of rivers, streams, ditches and ponds in an agricultural landscape in Southern England.

10 Biological Conservation 115: 329-341

11 Whittaker, R. J. \& Fernandez-Palacios, J. M. 2007. Island Biogeography: Ecology, Evolution, and 12 Conservation. Oxford University Press: Oxford

13 Wood, P. J., Greenwood, M. T., Barker, S. A. \& Gunn, J. 2001. The effects of amenity management 14 for angling on the conservation value of aquatic invertebrate communities in old industrial mill ponds.

15 Biological Conservation 102: 17-29

16 Wood, P.J., Greenwood, M. T. \& Agnew, M. D. 2003. Pond biodiversity and habitat loss in the UK. 17 Area 35: 206-2 
2 Table 1 - Summary of Pearson's Correlation Coefficients between environmental parameters and

3 biotic indices.

\begin{tabular}{|c|c|c|c|c|}
\hline & $\begin{array}{l}\text { Taxon } \\
\text { Number }\end{array}$ & $\begin{array}{l}\text { Shannon Wiener } \\
\text { Diversity index }\end{array}$ & $\begin{array}{l}\text { Berger Parker } \\
\text { Dominance index }\end{array}$ & $\begin{array}{l}\log _{10} \\
\text { Abundance }\end{array}$ \\
\hline $\log _{10}$ Area & $0.823 * *$ & $0.704 * *$ & $-0.600 * *$ & $0.432 * *$ \\
\hline $\log _{10}$ Depth & $0.601 * *$ & $0.313 *$ & -0.121 & $0.445 * *$ \\
\hline $\log _{10}$ Water Surface Shaded & 0.000 & 0.106 & -0.224 & $0.359^{*}$ \\
\hline $\log _{10}$ Pond Margin Shaded & 0.297 & $0.348 *$ & $-0.387 *$ & $0.399 * *$ \\
\hline $\log _{10}$ Emergent Macrophyte & 0.178 & 0.284 & -0.292 & 0.015 \\
\hline $\log _{10}$ Submerged Macrophyte & 0.304 & 0.198 & -0.069 & $0.359 *$ \\
\hline $\log _{10}$ Floating Macrophyte & $-0.347^{*}$ & -0.318 & 0.291 & 0.126 \\
\hline $\log _{10}$ Conductivity & -0.006 & 0.156 & -0.245 & -0.095 \\
\hline $\log _{10}$ Dissolved Oxygen & $0.346^{*}$ & 0.267 & -0.175 & 0.160 \\
\hline $\mathrm{pH}$ & 0.006 & 0.015 & 0.072 & -0.208 \\
\hline Pond Proximity & 0.253 & 0.293 & $-0.314 *$ & -0.022 \\
\hline Pond Connectivity & $0.375^{*}$ & $0.414 * *$ & $-0.418 * *$ & 0.019 \\
\hline$* \mathrm{P}<0.05$ & & & & \\
\hline$* * \mathrm{P}<0.01$ & & & & \\
\hline
\end{tabular}

6

7

8

9

10

11

12

13

14

15 


\section{Figure Captions}

2 Fig. 1 Scatter plots of the relationship between pond surface area $\left(\log _{10}\right)$ and

3

4

5

6

$7 \quad$ Fig. 2

8

9

10

11

$12 \quad$ Fig. 3

13

14

15

16

17

18

19

20

21

22

23

24

25

macroinvertebrate community indices; (a) abundance $\left(\log _{10}\right)$, (b) taxon richness, (c)

Shannon Wiener Diversity index and (d) Berger Parker Dominance index. Open symbols $=$ park ponds, grey symbols $=$ other urban ponds and solid black symbols $=$ garden ponds.

Macroinvertebrate diversity indices (mean $+/$ - 1SE) recorded within different microhabitats (open water, emergent macrophytes, submerged macrophytes and floating macrophytes) for garden, other urban and park ponds: (a) abundance $\left(\log _{10}\right)$, (b) taxon richness, (c) Shannon Wiener Diversity index and (d) Berger Parker Dominance index.

RDA site plots of macroinvertebrate communities recorded from the three urban pond types (garden, other urban and park ponds) studied around the town of Loughborough (Leicestershire, UK): (a) site plot with significant environmental vectors ( $\mathrm{SM}=$ submerged macrophytes, EM= emergent macrophytes), note - only significant environmental parameters are presented; (b) taxa richness bubble plot; and (c) Shannon Wiener Diversity index bubble plot. Note: the size of each bubble is proportional to the absolute values represented.

Fig. 4 RDA taxon plot for garden, other urban and park pond macroinvertebrate assemblages with significant environmental vectors data $(\mathrm{SM}=$ submerged macrophytes, EM= emergent macrophytes). Note - only significant environmental parameters are presented. 
$1 \quad$ Fig. 1

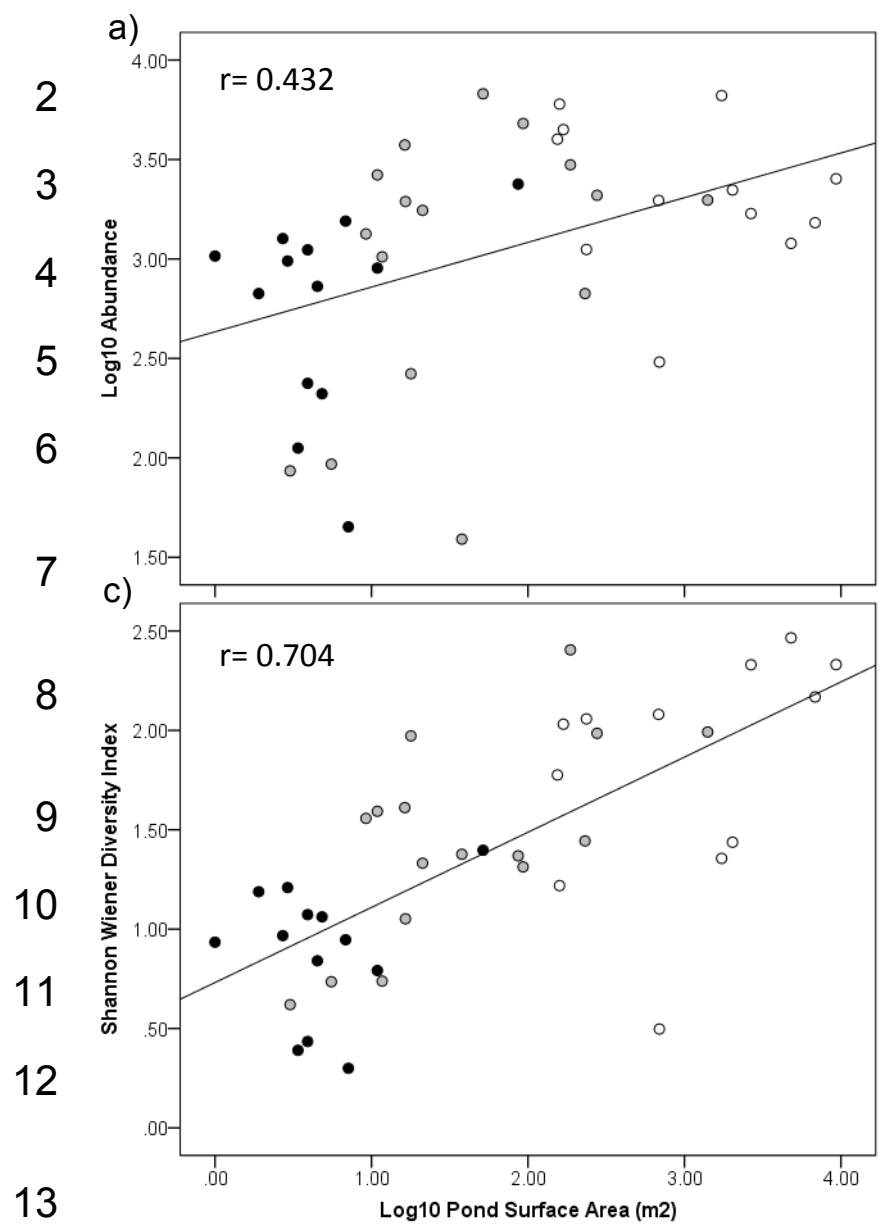

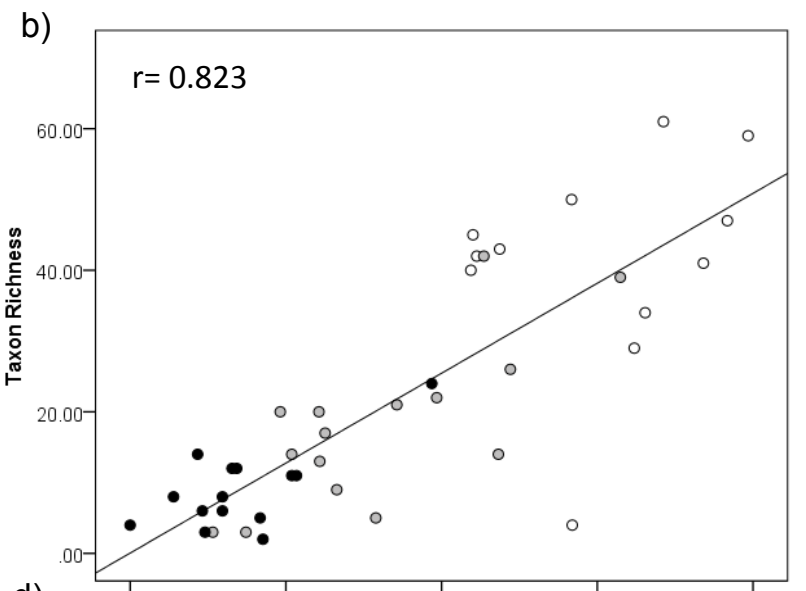

d)

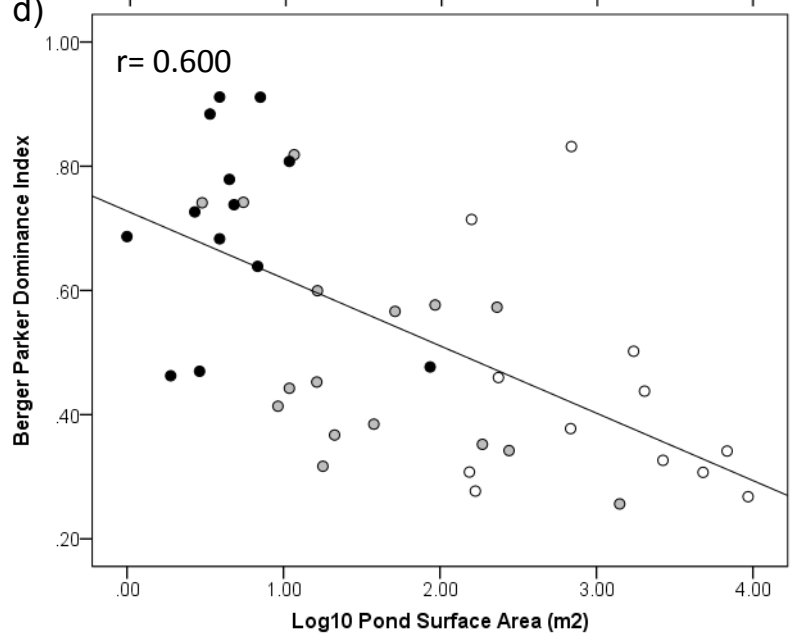


1 Fig. 2

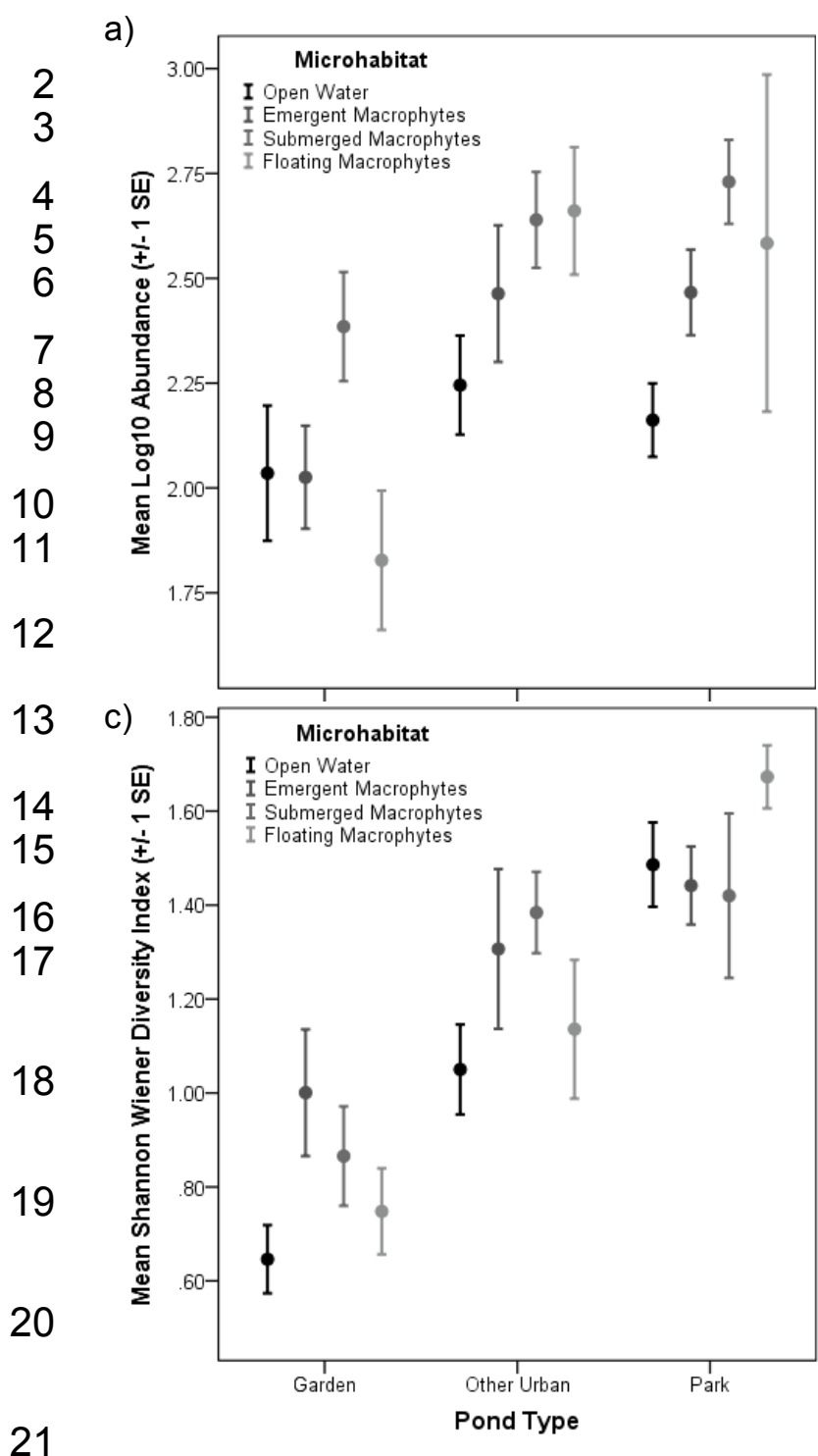

b)

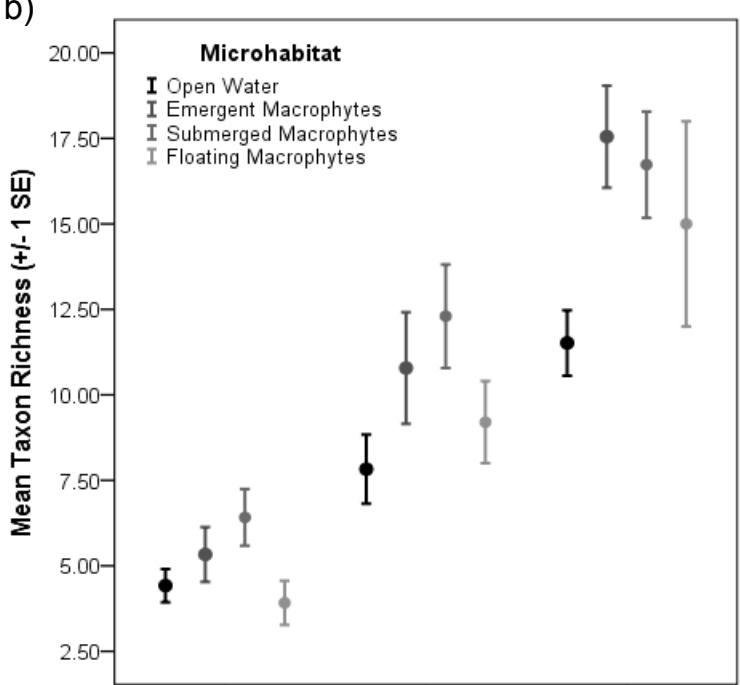

d)

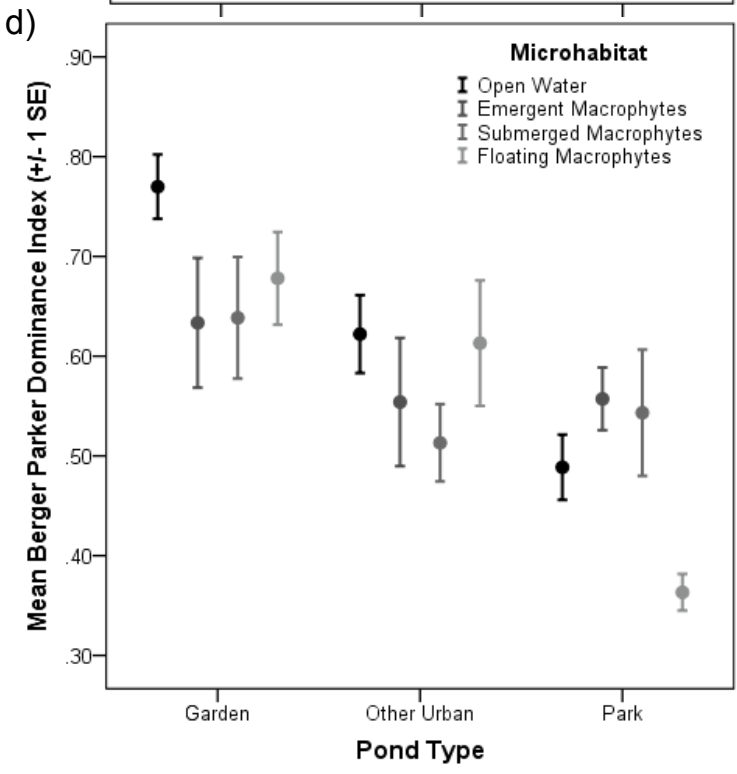


1 Fig. 3
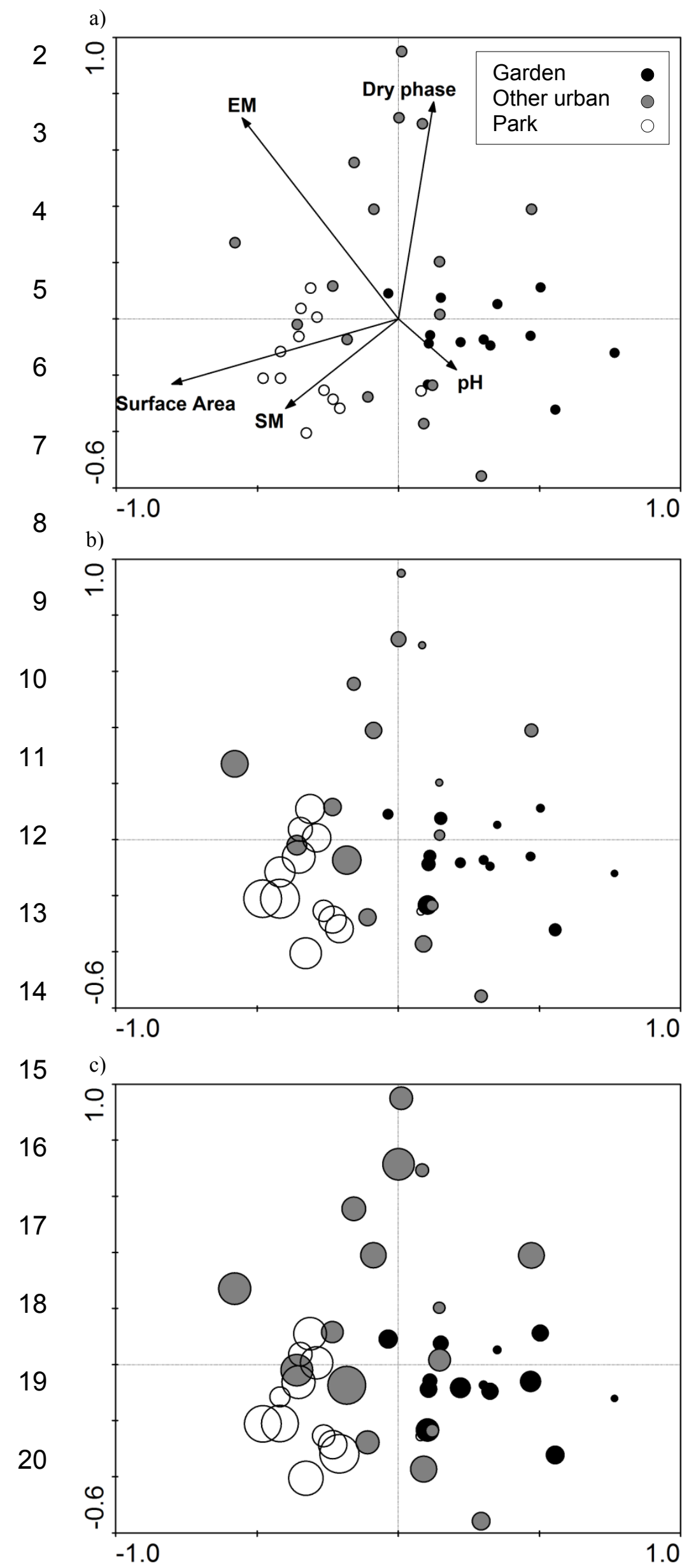
1 Fig. 4

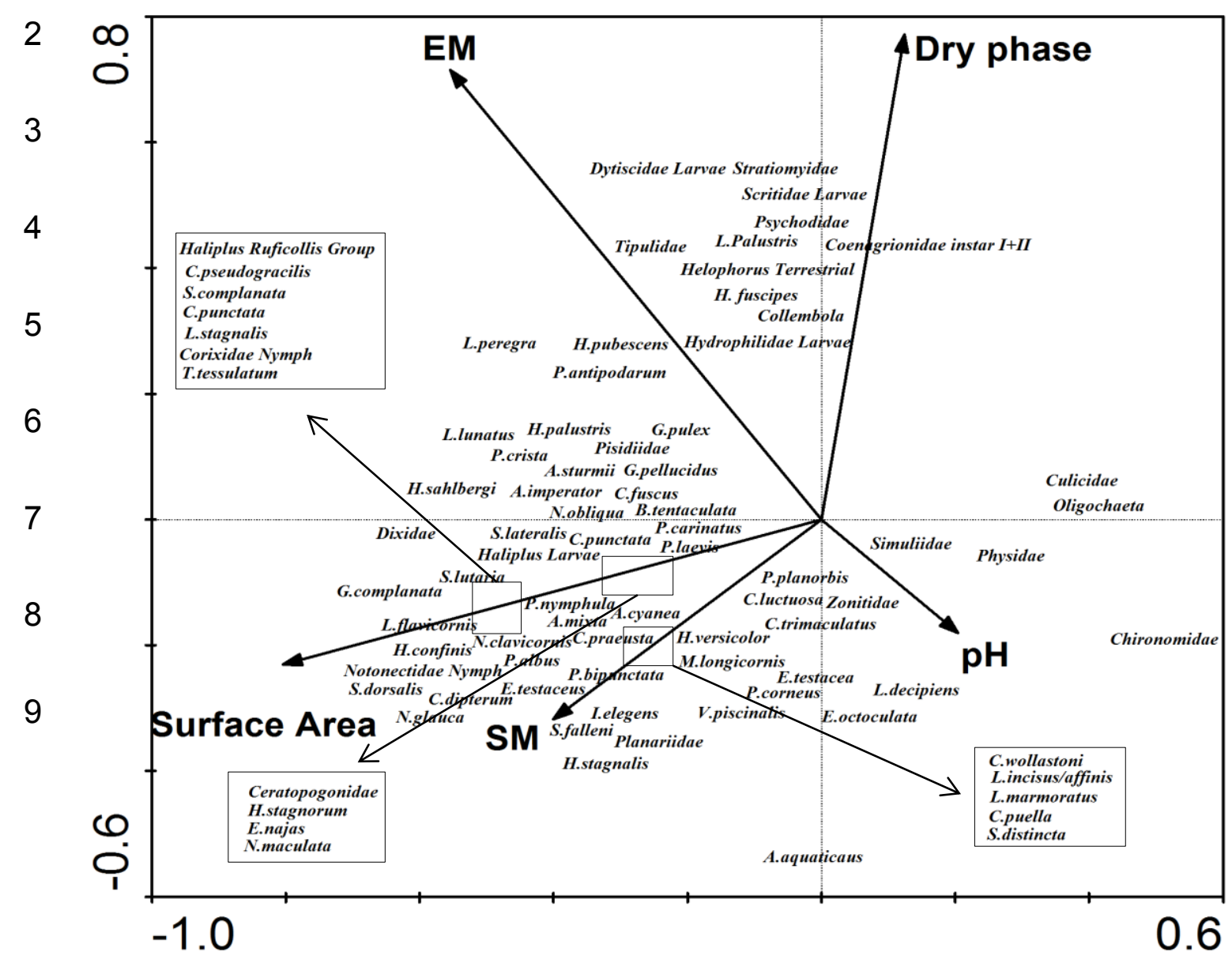

